Article

\title{
Enhanced Electrical Properties of Alkali-Doped ZnO Thin Films with Chemical Process
}

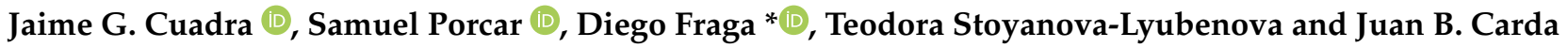 \\ Department of Inorganic and Organic Chemistry, University Jaume I, 12071 Castellon de la Plana, Spain; \\ jcuadra@uji.es (J.G.C.); saporcar@uji.es (S.P.); Teodora.LYUBENOVA-STOYANOVA@ec.europa.eu (T.S.-L.); \\ carda@uji.es (J.B.C.) \\ * Correspondence: fraga@uji.es
}

Citation: Cuadra, J.G.; Porcar, S.; Fraga, D.; Stoyanova-Lyubenova, T.; Carda, J.B. Enhanced Electrical Properties of Alkali-Doped ZnO Thin Films with Chemical Process. Solar 2021, 1, 30-40. https://doi.org/ $10.3390 /$ solar1010004

Academic Editor: Jürgen

Heinz Werner

Received: 22 October 2021

Accepted: 22 November 2021

Published: 24 November 2021

Publisher's Note: MDPI stays neutral with regard to jurisdictional claims in published maps and institutional affiliations.

Copyright: (c) 2021 by the authors. Licensee MDPI, Basel, Switzerland. This article is an open access article distributed under the terms and conditions of the Creative Commons Attribution (CC BY) license (https:/ / creativecommons.org/licenses/by/ $4.0 /)$.

\begin{abstract}
Doped $\mathrm{ZnO}$ are among the most attractive transparent conductive oxides for solar cells because they are relatively cheap, can be textured for light trapping, and readily produced for large-scale coatings. Here, we focus on the development of alternative $\mathrm{Na}$ and $\mathrm{K}$-doped $\mathrm{ZnO}$ prepared by an easy low-cost spray pyrolysis method for conducting oxide application. To enhance the electrical properties of zinc oxide, alkali-doped $\mathrm{Zn}_{1-x} \mathrm{M}_{\mathrm{x}} \mathrm{O}(\mathrm{x}=0.03)$ solid solutions were investigated. The resulting layers crystallize in a single hexagonal phase of wurtzite structure with preferred c-axis orientation along a (002) crystal plane. Dense, well attached to the substrate, homogeneous and highly transparent layers were obtained with great optical transmittance higher than $80 \%$. The optical energy band gap of doped $\mathrm{ZnO}$ films increase from 3.27 to $3.29 \mathrm{eV}$ by doping with $\mathrm{Na}$ and $\mathrm{K}$, respectively. The electrical resistivity of the undoped $\mathrm{ZnO}$ could be decreased from $1.03 \times 10^{-1} \Omega$.cm to $5.64 \times 10^{-2} \Omega . c m$ (K-doped) and $3.18 \times 10^{-2}$ (Na-doped), respectively. Lastly, the carrier concentrations increased from $5.17 \times 10^{17}$ (undoped $\mathrm{ZnO}$ ) to $1 \times 10^{18}$ (doped $\mathrm{ZnO}$ ).
\end{abstract}

Keywords: oxide materials; semiconductors; thin films; electronic properties

\section{Introduction}

Transparent conductive oxides (TCOs) are suitable materials for photovoltaic (PV) applications, light-emitting diodes, and others that can be functionalized depending on the requisites of its uses [1-3]. For many years, numerous other materials and devices have been proven with the ultimate goal to make photovoltaic energy widely available. Thin film technology is a suitable option for the replacement of the classical silicon crystalline solar cells [4]. The request of the TCOs layers needs high transparency as well as a low sheet resistivity. Most of the current commercial devices are designed with tin-doped indium oxide $\mathrm{In}_{2} \mathrm{O}_{3}: \mathrm{Sn}$ (ITO) and fluorine-doped tin oxide $\mathrm{SnO}_{2}: \mathrm{F}$ (FTO) due to their good optical and electrical features [5-7]. Mainly, ITO is the most widely used TCO, because of its two crucial properties, its excellent electrical conductivity and optical transmittance [8,9].

In contrast, $\mathrm{TCO}$ based on $\mathrm{ZnO}$ films are widely used because they are relatively cheap, can be modulated for light absorption and readily shaped for large-scale coatings [10,11]. The direct bandgap for $\mathrm{ZnO}$ is $\mathrm{E}_{\mathrm{G}}=3.37 \mathrm{eV}$, so these may lead to many applications, for example, in photonics [12]. On the other hand, the high exciton binding energy that $\mathrm{ZnO}$ has, around $60 \mathrm{meV}$ at room temperature, is an important material property regard. In addition, $\mathrm{ZnO}$ is resistant to oxygen and moisture and it has very good optical transparency, easy solution processing, and a flexible host crystal lattice able to accept a variety of dopant substitutions [13]. ZnO exhibits an unintentional n-type character; it possesses a high number of electron donors. Additional doping could increase the donor concentration [14] It is well known that the process of thin films doping with elements of group 13 of the periodic table (Al, Ga, and In) improves its electrical properties $[15,16]$. Another material property for a high number of applications where the electronic charge has to be transmitted is the mobility of charge carriers (electrons and holes). The values of the electron and holes 
mobility are also highly important considering the potential of this material in applications such as TCO: thanks to this, $\mathrm{ZnO}$ exhibits high charge carrier mobilities as compared to other compounds used in photovoltaic devices [17]. Different technologies for the preparation of TCOs layers are used, predominantly physical techniques such as magnetron sputtering and chemical vapor deposition [18], instead of chemical routes (sol-gel or spray pyrolysis) [19]. In general, chemical methods are promising ways for TCOs production due to their efficient material use and high throughput. The uses of sodium (Na) such as a $\mathrm{ZnO}$ dopant to obtain p-type heterojunctions onto $\mathrm{Si}$ or (1-102) sapphire substrates was researched, and they conclude the importance of Na concentration for exhibit n- or p-conductivity [20,21]. Recently, several groups reported obtaining p-type of $\mathrm{ZnO}$ by potassium (K) [22,23]; although, the deposited ZnO:K onto glass substrate suffers the same problem or exhibits $\mathrm{n}$ - or $\mathrm{p}$-conductivity depending on the $\mathrm{K}$ doping, and the results of resistivity will also improve [24].

In this context, the influences of alkali doping ( $\mathrm{Na}$ and $\mathrm{K}$ ) on the $\mathrm{ZnO}$ properties were investigated. In this paper, we report the electrical, optical, and photochemical properties of doped $\mathrm{ZnO}\left(\mathrm{Zn}_{0.97} \mathrm{M}_{0.03} \mathrm{O}\right.$, where $\left.\mathrm{M}=\mathrm{Na}, \mathrm{K}\right)$ thin films prepared by low-cost and facile spray pyrolysis deposition onto a soda-lime glass substrate.

\section{Materials and Methods}

\subsection{Synthesis and Deposition}

A solid solution of $\mathrm{Na}$ and $\mathrm{K}$-doped $\mathrm{ZnO}\left(\mathrm{Zn}_{1-\mathrm{x}} \mathrm{M}_{\mathrm{x}} \mathrm{O}, \mathrm{x}=0.03\right)$ was prepared by the spray pyrolysis method [25]. Undoped $\mathrm{ZnO}$ for comparison studies was synthesized using the same method. The raw materials applied for the desired compounds were: $\mathrm{Zn}\left(\mathrm{CH}_{3} \mathrm{COO}\right)_{2} \cdot 2 \mathrm{H}_{2} \mathrm{O}$ (PanReac Applichem, 99.5\%,), $\mathrm{Na}\left(\mathrm{CH}_{3} \mathrm{COO}\right)$ (Labkem, 99.9\%), and $\mathrm{KNO}_{3}$ (Labkem, 99\%). The precursor solution was performed by dissolving the alkaline salts into the mixture of ethanol (EtOH) $(25 \mathrm{~mL})$ and methanolamine (MEA- $\mathrm{C}_{2} \mathrm{H}_{7} \mathrm{NO}$ ) $(1.12 \mathrm{~mL})$ in $\mathrm{M}^{+} / \mathrm{Zn}^{3+}(\mathrm{M}=\mathrm{Na}, \mathrm{K})$ molar ratio $=3 \%$; under constant stirring on a hot plate at room temperature.

The resulting solutions were applied by handmade Dual Action Gravity Feed Airbrush with flow rate was $5.75 \mathrm{~mL} / \mathrm{min}$ onto a soda-lime glass substrate, previously treated by a mixture of $\mathrm{HCl}: \mathrm{HNO}_{3}$ (1:2) for surface texturing. Then, the samples were heated at $425^{\circ} \mathrm{C}$ at atmospheric pressure on a hot plate to eliminate the organic compounds. To increase the crystallinity of the coating, thermal treatment at $350{ }^{\circ} \mathrm{C}$ (heating rate $20^{\circ} \mathrm{C} / \mathrm{min}$ in a reductive atmosphere was performed.

\subsection{Characterization Techniques}

The crystal structure of doped $\mathrm{ZnO}$ thin film was studied using Grazing incidence X-ray diffraction (GIXRD) measurements. X-ray diffractometer (D4 Endeavor, BurkerASX) equipped with a $\mathrm{Cu} \mathrm{K} \alpha$ radiation source was used. Data was collected by stepscanning from $10^{\circ}$ to $80^{\circ}$ with a step size of $0.05^{\circ} 2 \theta$ and $3 \mathrm{~s}$ counting time per step. The measurements were performed at a grazing-incident angle, greater than the so-called critical angle for total external reflection, at which X-rays penetrate the sample. The critical angle (around $1^{\circ}$ ) was determined experimentally.

Scanning electron microscopy (SEM) model JEOL 7001F was employed to study the morphology of the films. The layer thickness was determined from cross-section micrographs. The surface chemical analysis was investigated by $\mathrm{X}$-ray photoelectron spectroscopy (XPS) on a Sage 150 photoelectron spectrometer for the multi-technique surface analysis system. This system was equipped with a MAC 2 CAMECA RIBER double stage cylindrical mirror electron-energy analyzer. The photon source was a CAMECA SCX 700 dual anode X-ray. A non-monochromatized $\mathrm{Al} \mathrm{K} \alpha$ X-ray source $(\mathrm{h} v=1486.6 \mathrm{eV})$ was used as the excitation source in all cases. Electrical measurements were carried out by the four-probe method using Ossila T2001A3 with a target current of $0.001 \mathrm{~A}$ and a voltage increment of $0.01 \mathrm{~V}$ per point to a maximum of $10 \mathrm{~V}$ to obtain the sheet resistance and resistivity data. 
The optical properties and band gap energy of the TCOs were conducted by UV-visNIR spectroscopy in the wavelength range $200-1000 \mathrm{~nm}$ (step size $1 \mathrm{~nm}$ ) using a Cary 500 Scan Varian spectrophotometer. The transmittance spectra were obtained applying $\mathrm{BaSO}_{4}$ integrating sphere as white reference material.

The photoelectrochemical measurements were realize in a three-electrode system. The $\mathrm{Na}$, and $\mathrm{K}$-doped $\mathrm{ZnO}$ onto a soda-lime glass substrate was used as a working electrode having a surface area of about $0.6 \mathrm{~cm}^{2}, \mathrm{Pt}$ wire was used as work electrode and $\mathrm{Ag} / \mathrm{AgCl}$ was used as a reference electrode, respectively. The electrolyte used for the measure was $1 \mathrm{M}$ $\mathrm{KCl}$ solution. The measurements were carried out with Autolab potentiostat/galvanostat PGSTAT302. Electrochemical impedance spectroscopy (EIS) measurements were completed between $50 \mathrm{mHz}$ and $1 \mathrm{MHz}$ with $20 \mathrm{mV}$ amplitude perturbation, with a step potential of $64 \mathrm{mV}$ in the anodic direction. The EIS data were evaluated with ZView software (Scribner Associates).

\section{Results and Discussion}

\subsection{Crystallographic Properties of $M-D o p e d ~ Z n O ~(M=N a, K)$ Thin Films}

In this study, structural changes in $\mathrm{ZnO}$ films deposited onto a soda-lime glass as a result of $\mathrm{Na}$ or $\mathrm{K}$ incorporation have been studied by Grazing incidence X-ray diffraction (GIXD). XRD patterns of undoped $\mathrm{ZnO}, \mathrm{ZnO}: \mathrm{Na}$, and $\mathrm{ZnO}: \mathrm{K}$ thin films were shown in Figure 1. All films show a strong peak at $2 \theta$ near $34,42^{\circ}$ and weak peaks at $31.80^{\circ}, 36.21^{\circ}$, $56.60^{\circ}, 62.85^{\circ}$, and $67.94^{\circ}$ could be assigned, respectively, to the (002), (100), (101), (110), (103), and (112) crystal planes. This preferred c-axis orientation along the (002) plane is not new, it can be seen in other studies with different types of deposition techniques [26,27]. $\mathrm{ZnO}$ wurtzite structure could be occupied in principle by a $\mathrm{Zn}$ interstitial atom $\left(\mathrm{Zn}_{\mathrm{i}}\right)$ in the tetrahedral site or the octahedral site. Zn interstitial will be more stable at the octahedral site where the geometrical constraints are less relentless. Moreover, the density-functional calculations indicate a large displacement of $Z n_{i}$ along the c-axis instead of occupying the ideal octahedral site, resulting in an increased $\mathrm{Zn}_{\mathrm{i}}-\mathrm{Zn}$ distance $[28,29]$. Furthermore, all the observed diffraction peaks for TCO films which correspond to Bragg reflections of the wurtzite structure (JCPDS File No.79-2205). The absence of impurity peak shows that as-obtained films are highly phased pure. The different TCO thin films change the intensity, but the peak position does not change, depending on the type of doping within the sensitivity of the method.

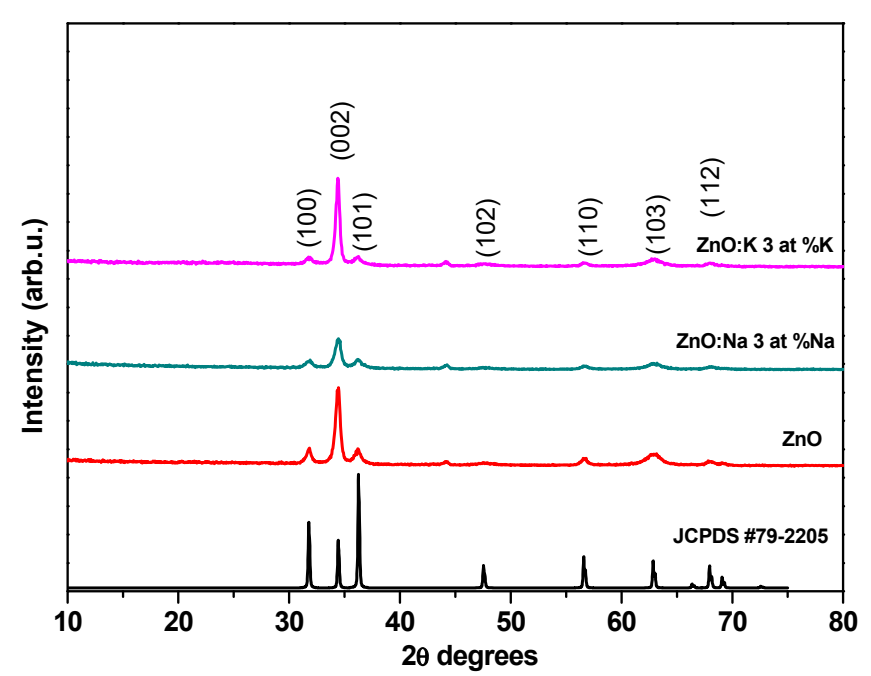

Figure 1. X-ray diffraction patterns of undoped, Na-doped, and K-doped $\mathrm{ZnO}$ thin films. 


\subsection{Morphological and Structural Properties of $M$-Doped $\mathrm{ZnO}(M=N a$, K) Thin Films}

Figure 2 shows the plan and cross-section images of the M-doped $\mathrm{ZnO}$ thin films. In all cases, dense and well attached homogeneous layers were observed in terms of particle size and distribution. Furthermore, a good separation could be seen between the film and the soda glass. The samples showed a thickness between $600 \mathrm{~nm}$ and $740 \mathrm{~nm}$ due to the manual method used.

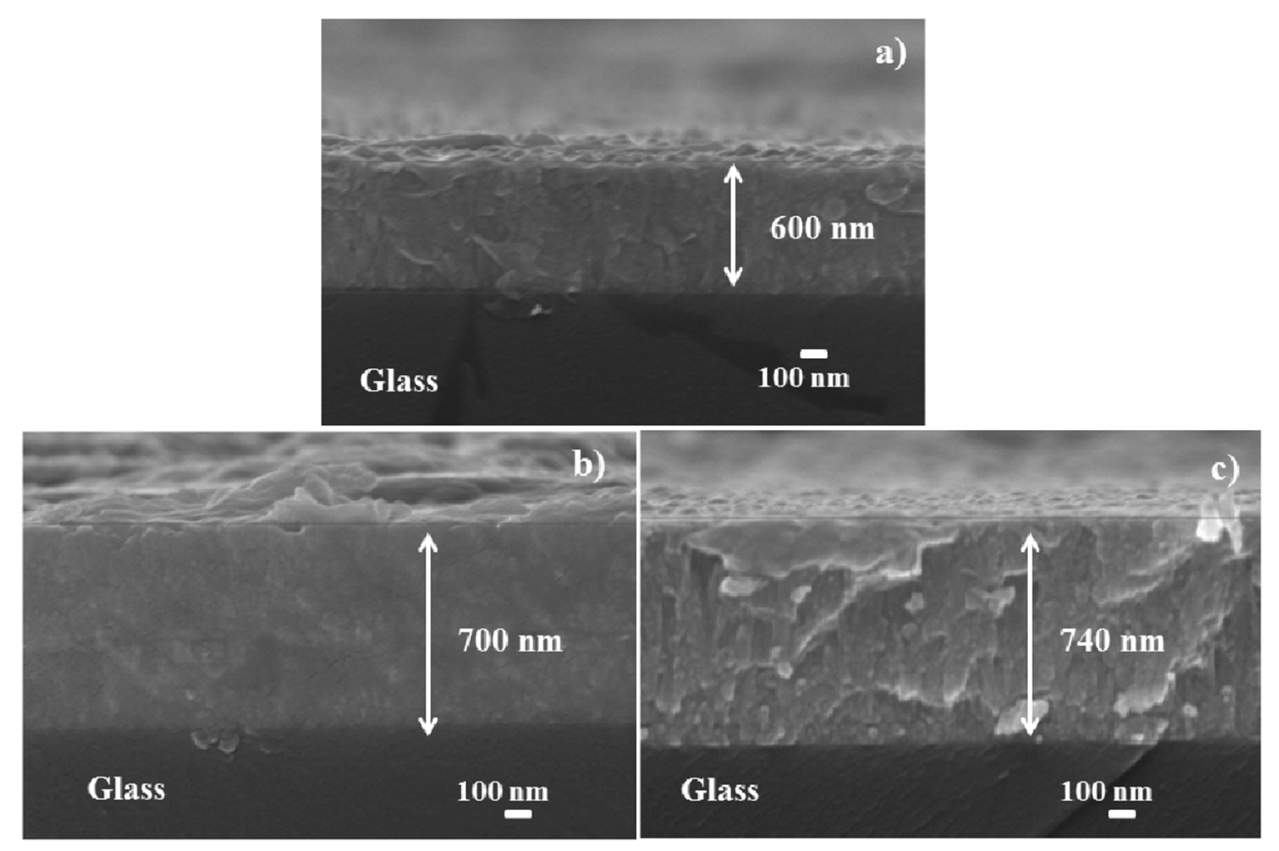

Figure 2. Cross-section images (a) $\mathrm{ZnO}$, (b) $\mathrm{ZnO}: \mathrm{Na}$, and (c) $\mathrm{ZnO}: \mathrm{K}$ thin films.

To calculate the contained of the different dopant concentration in the films and to determinate the chemical state of the film composing elements, XPS analysis was carried out for undoped, $3 \% \mathrm{Na}$ and $3 \% \mathrm{~K}$-doped $\mathrm{ZnO}$ films, and calibrated according to the $\mathrm{C} 1 \mathrm{~s}$ peak at $285 \mathrm{eV}$. The XPS results confirm that $\mathrm{Na}$ and $\mathrm{K}$ elements have been doped into the $\mathrm{ZnO}$ film but the value of the atomic percentage of M-dopants in the thin film surface was variable. In the case of $\mathrm{Na}$ and $\mathrm{K}$, the percentage the values of atomic percentage in the surface of the thin film ( $2.8 \%$ and $2.1 \%$, respectively) are smaller than expected in the nominal composition in the solution ( $3 \%$ of dopant).

Figure 3a gives XPS data of the $\mathrm{Zn} 2 \mathrm{p} 3 / 2$ in the undoped $\mathrm{ZnO}$ films, Na and K-doped $\mathrm{ZnO}$ films. These peaks could be attributed to the position of $\mathrm{Zn} 2 \mathrm{p}$ in pure $\mathrm{ZnO}$, and no metallic $\mathrm{Zn}$ with binding energy about $1021.6 \mathrm{eV}$ is observed; it concludes that $\mathrm{Zn}$ can only found as the oxidized state. The $\mathrm{Zn}$ binding energy decreases while $\mathrm{O}$ binding energy increases when comparing undoped $\mathrm{ZnO}$ to $\mathrm{Na}$ or $\mathrm{K}$-doped $\mathrm{ZnO}$ in the XPS data by other authors [30].

XPS spectrum and simulated lines of $\mathrm{Na}$ 1s in the $\mathrm{ZnO}: \mathrm{Na}$ film is shown in Figure 3b. The peak position was at the binding energy of $1071.10 \mathrm{eV}$. This binding energy corresponds to $\mathrm{Na}^{+}$oxide; it concludes that $\mathrm{Na}$ element doped as $\mathrm{Na}^{+}$in the Na-doped $\mathrm{ZnO}$ film. Figure $3 c$ reveals that $K$ has been doped into $\mathrm{ZnO}$ crystal by the $\mathrm{K} 2 \mathrm{p}$ peaks that are observed in Figure $3 \mathrm{~b}$, similarly to previously report [31]. The binding states of $\mathrm{O} 1 \mathrm{~s}$ coming from to the undoped $\mathrm{ZnO}, \mathrm{ZnO}: \mathrm{Na}$, and $\mathrm{ZnO}: \mathrm{K}$ are shown in Figure 3d. The asymmetric $\mathrm{O} 1$ s peak was coherently fitted by three Gaussian components, which are low binding energy peak $\left(\mathrm{O}_{\mathrm{A}}\right)$, medium binding energy peak $\left(\mathrm{O}_{\mathrm{B}}\right)$, and high binding energy peak (Oc) [32]. The $\mathrm{O}_{\mathrm{A}}$ peak of the 1 s spectrum could be associated to the $\mathrm{O}^{2-}$ ions on the wurtzite structure of the hexagonal $\mathrm{Zn}^{2+}$ ion array, which are encircled by zinc atoms with the full supplement of neighbor $\mathrm{O}^{2-}$ ions [33]. Therefore, The $\mathrm{O}_{\mathrm{A}}$ peak of the $1 \mathrm{~s}$ spectrum can be related to the $\mathrm{Zn}-\mathrm{O}$ bonds [34]. The higher-binding energy $\left(\mathrm{O}_{C}\right)$ is related 
to chemisorbed or dissociated oxygen or different species; for example, $\mathrm{OH}$ species on the surface of the $\mathrm{ZnO}$ films; for instance, $\mathrm{CO}_{3}$, adsorbed $\mathrm{H}_{2} \mathrm{O}$, or absorbed $\mathrm{O}_{2}$ [35]. The $\mathrm{O}_{\mathrm{B}}$ of the $\mathrm{O}$ 1s peak is related to $\mathrm{O}^{2-}$ ions that are in oxygen-deficient regions in the $\mathrm{ZnO}$ matrix [36,37]. The difference between the intensity of the peaks could attribute with the variation in the concentration of the oxygen vacancies $\left(\mathrm{V}_{\mathrm{O}}\right)$ [38]. The intensity of $\mathrm{O}_{\mathrm{A}}$ peaks in comparison with $\mathrm{O}_{\mathrm{B}}$ and $\mathrm{O}_{\mathrm{C}}$ explains the strong $\mathrm{Zn}-\mathrm{O}$ bonding in $\mathrm{ZnO}$ thin films, the value of the binding energy for the different peaks $\left(\mathrm{O}_{A}, \mathrm{O}_{\mathrm{B}}\right.$, and $\left.\mathrm{O}_{C}\right)$ decrease when comparing undoped $\mathrm{ZnO}$ to $\mathrm{Na}$ or $\mathrm{K}$-doped $\mathrm{ZnO}$ in other words when the atomic radio of the dopant increases the bonding energy of $\mathrm{Zn}$-O decrease owning to the wurtzite structure was distorted.
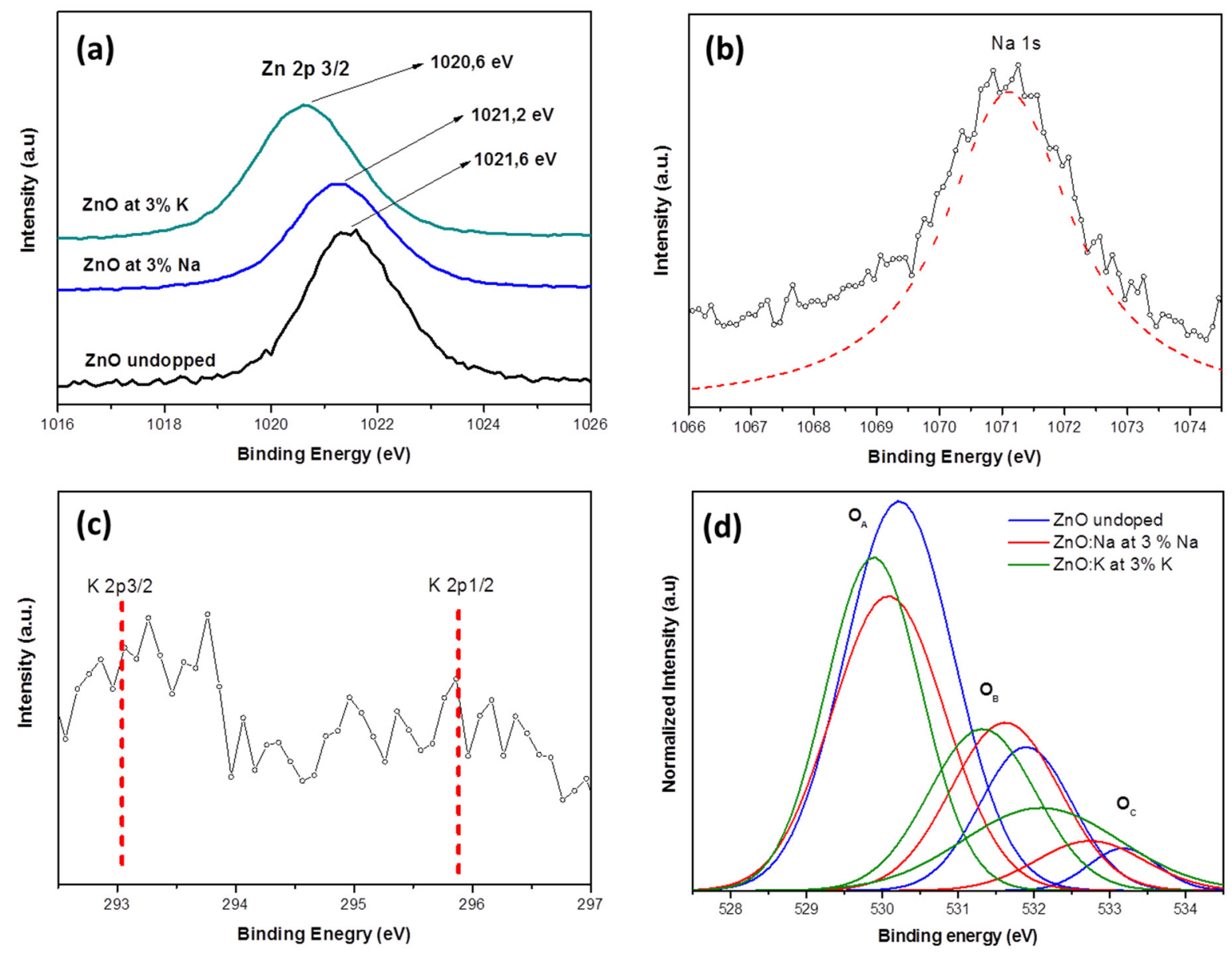

Figure 3. (a) XPS spectra of the $\mathrm{Zn} 2 \mathrm{p} 3 / 2$ in the undoped $\mathrm{ZnO}, \mathrm{ZnO}: \mathrm{Na} 3 \%$, and $\mathrm{ZnO}: \mathrm{K} 3 \%$ films. (b) XPS spectrum and simulated lines of $\mathrm{Na} 1 \mathrm{~s}$ in the ZnO:Na 3\%. (c) XPS spectrum of the K 2p in ZnO:K 3\%. (d) Oxygen 1s spectra of ZnO, $\mathrm{ZnO}: \mathrm{Na}$, and $\mathrm{ZnO}: \mathrm{K}$ thin films.

\subsection{Optical and Electrical Properties of $M$-Doped $\mathrm{ZnO}(M=N a, K)$ Thin Films}

Figure 4 exhibit the optical transmittance spectra of undoped and doped $\mathrm{ZnO}$ thin films deposited on a soda-lime substrate. In the visible region with wavelengths ranging from $400 \mathrm{~nm}$ to $800 \mathrm{~nm}$, all the samples were highly transparent with the average optical transmittance of $80 \%$ and $78 \%$ for $\mathrm{Na}$ and $\mathrm{K}$ dopants, respectively. The crystal dimensions were similar in the three dopants; therefore, the values of the transmittance were related to the thickness of the films when the thickness increased the value of the transmittance decreased. 


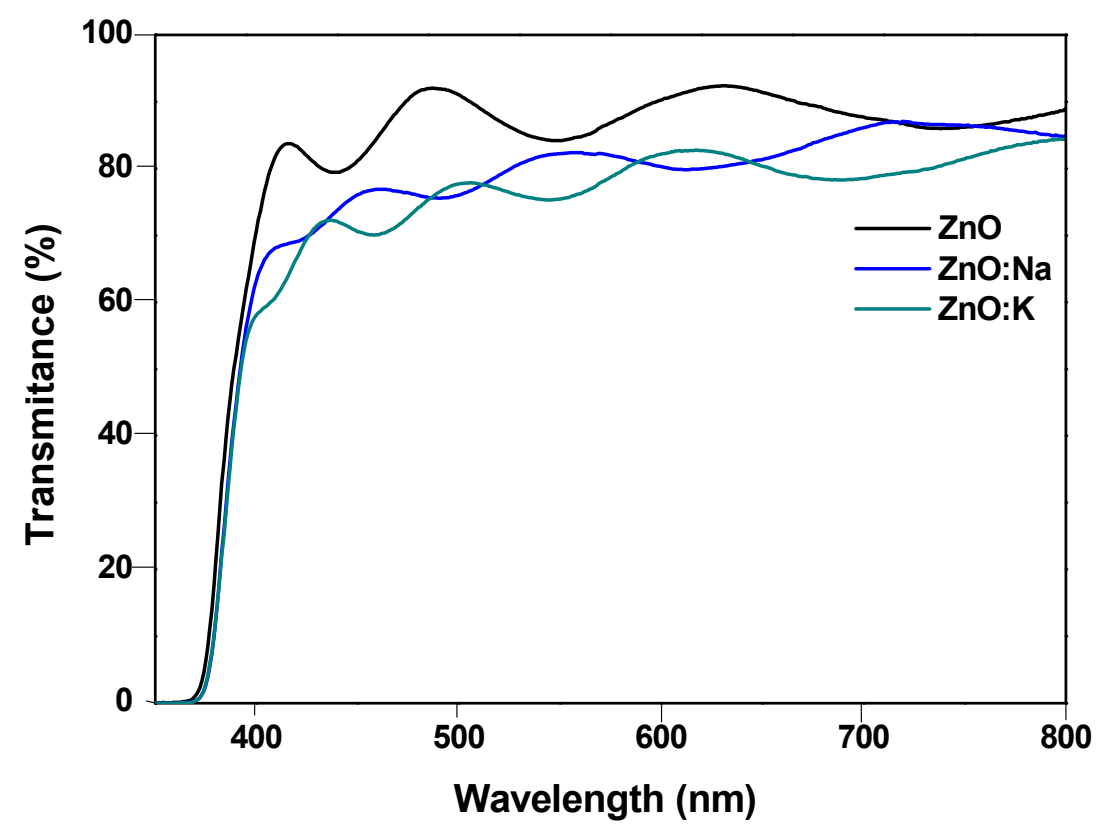

Figure 4. Optical transmittance and absorption spectra of M-Doped $\mathrm{ZnO}$ thin films.

The absorption coefficient $(\alpha)$ values were calculated using Lambert's Law as the following equation [39]:

$$
\alpha=\frac{1}{t} \ln \left(\frac{1}{T}\right)
$$

where $t$ is the film thickness and $T$ is the transmittance. An optical band gap of thin films was estimated using the equation $\mathrm{x}$ by the extrapolation of $(\alpha h v)^{2}$ vs. $h v$.

$$
\alpha h v=A\left(h v-E_{g}\right)^{\frac{1}{2}}
$$

where $h v$ is the photon energy, $A$ is a constant, and $E_{g}$ is the optical band gap. $\mathrm{ZnO}$, $\mathrm{ZnO}: \mathrm{Na}$ and $\mathrm{ZnO}: \mathrm{K}$ films optical band gaps are shown in Figure 5, the energy band gap was determined by extrapolating linear region of the plot to energy axis where $\alpha^{2}=0$ [40].

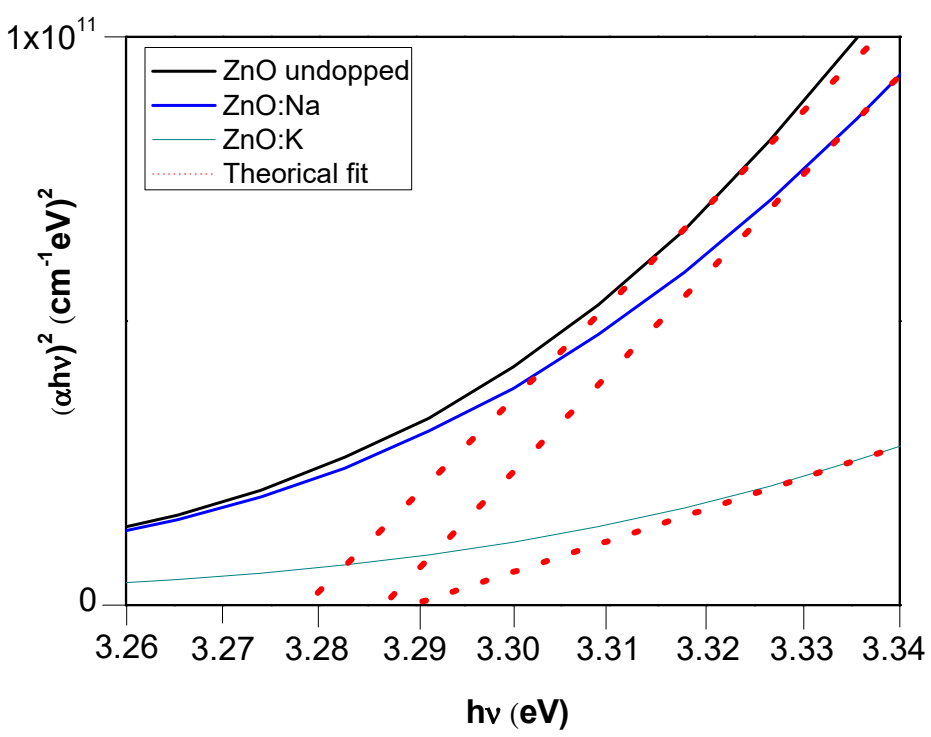

Figure 5. Relation of $(\alpha h v)^{2}$ and $h v$ of M-doped $\mathrm{ZnO}$ thin films. $\mathrm{ZnO}, \mathrm{ZnO}: \mathrm{Na}$, and $\mathrm{ZnO}: \mathrm{K}$.

$\mathrm{ZnO}$ thin film presented a wide band gap of $3.28 \mathrm{eV}$. The optical band gap values of $\mathrm{ZnO}: \mathrm{Na}$ and $\mathrm{ZnO}: \mathrm{K}$ thin films were 3.285 and $3.29 \mathrm{eV}$, respectively. The fitting results show 
that the energy band gaps increased with an increase in the atomic radio of the dopant and suggests that the band gap could be tuned for the applications in various electronic and optical applications.

Electrical properties of the $\mathrm{ZnO}$ films doped with 3\% of different alkalines were measured at room temperature using a four-point probe working station are listed in Table 1 . The current-voltage characteristics were measured by a digital electrometer and stabilized power supply. The mobility was calculated multiplying the measured resistivity with the doping/carrier density.

Table 1. Electrical properties of M-doped $\mathrm{ZnO}$ thin films.

\begin{tabular}{|c|c|c|c|c|}
\hline $\begin{array}{l}\text { Dopants } \\
\text { (at } 3 \% \text { ) }\end{array}$ & $\begin{array}{l}\text { Resistivity } \\
(\Omega \mathrm{cm})\end{array}$ & $\begin{array}{l}\text { Mobility } \\
\left(\mathrm{cm}^{2} / \mathrm{Vs}\right)\end{array}$ & $\begin{array}{l}\text { Carrier Concentration } \\
\qquad\left(\mathrm{cm}^{-3}\right)\end{array}$ & $\begin{array}{c}\text { Conduction } \\
\text { Type }\end{array}$ \\
\hline Undoped $\mathrm{ZnO}$ & $1.03 \times 10^{-1}$ & $1 \times 10^{2}$ & $5 \times 10^{17}$ & $\mathrm{n}$ \\
\hline $\mathrm{Na}$ & $3.18 \times 10^{-2}$ & $1 \times 10^{2}$ & $1 \times 10^{18}$ & $\mathrm{n}$ \\
\hline K & $5.64 \times 10^{-2}$ & $9 \times 10^{1}$ & $1 \times 10^{18}$ & $\mathrm{n}$ \\
\hline
\end{tabular}

The method used a linear sequence of four equally-spaced tips that were pressed on the surface of the material. A small current I from a constant-current source was passed through the outer two probe tips and the voltage drop $V$ was measured between the inner two probe tips. The resistivity values were calculated using the following equation [41]

$$
\rho=C\left(\frac{V}{I}\right) w
$$

where $w$ is the thickness, $\rho$ the resistivity, $V$ the voltage, $C$ is a geometrical correction factor, and $I$ the current. At the limit when the probe tips spacing, s, was much less than the lateral dimension of the sample, $C$ becomes $(\pi / \ln 2)=4.54$. The following equation gives the electrical conductivity.

$$
\sigma=\frac{1}{\rho}
$$

where $\sigma$ is conductivity.

The samples showed a different value of resistivity, the lowest value was obtained for the $\mathrm{ZnO}$ :Na sample. $\mathrm{K}$ doping greatly increased the defect creation, and it could act as scattering centers, and it produced an increase in the resistivity because the mobility decreased; therefore, the value of the resistivity of $\mathrm{ZnO}: \mathrm{K}$ increased [42]. As a result, the presence of the alkali dopants, in our samples, always improved the value of resistivity than that of the undoped $\mathrm{ZnO}$ thin film.

The Mott-Schottky equation could be used to determine the flat-band potential and the carrier concentration of the semiconductor. Understanding its derivation was essential for this experiment because it reinforces many key concepts associated with the semiconductorelectrolyte interface. However, the starting point for the derivation is Poisson's [43].

$$
\frac{d^{2} \phi}{d x^{2}}=\frac{-\rho}{\varepsilon \varepsilon_{0}}
$$

where $\rho$ corresponds to the charge density at a position $x$ away from the semiconductor surface, $\varepsilon$ is the dielectric constant of the semiconductor, and $\varepsilon_{0}$ is the permittivity of free space. Using the Boltzmann distribution to describe the distribution of electrons in the space charge region and Gaus's law relating the electric field through the interface to the charge contained within that region, Poisson's equation can be solved to give the Mott-Schottky equation [44,45].

$$
\frac{1}{C^{2}}=\frac{2}{\varepsilon_{r} \varepsilon_{0} A^{2} e N_{D}}\left(V-V_{f-} \frac{\kappa_{B} T}{e}\right)
$$


where $C$ is the capacitance, $A$ is the interfacial area, $N_{D}$ the number of donors, $V$ the applied voltage, $V_{f}$ is the flat band potential, $\kappa_{B}$ is Boltzmann's constant, $T$ the absolute temperature (taken as $298 \mathrm{~K}$ ), and $e$ is the electron charge, $\varepsilon_{0}$ is the permittivity in the vacuum, and $\varepsilon_{r}$ is the relative permittivity of soda-lime glass (taken as 7.3) [46].

Therefore, a plot of $C^{-2}$ vs. $V$ (Figure 6) should yield a straight line from which $V_{f}$ can be determined from the intercept on the $V$ axis. The value of $N_{D}$ can also be conveniently found from the slope knowing $\varepsilon_{0}, \varepsilon_{r}$, and $A$.
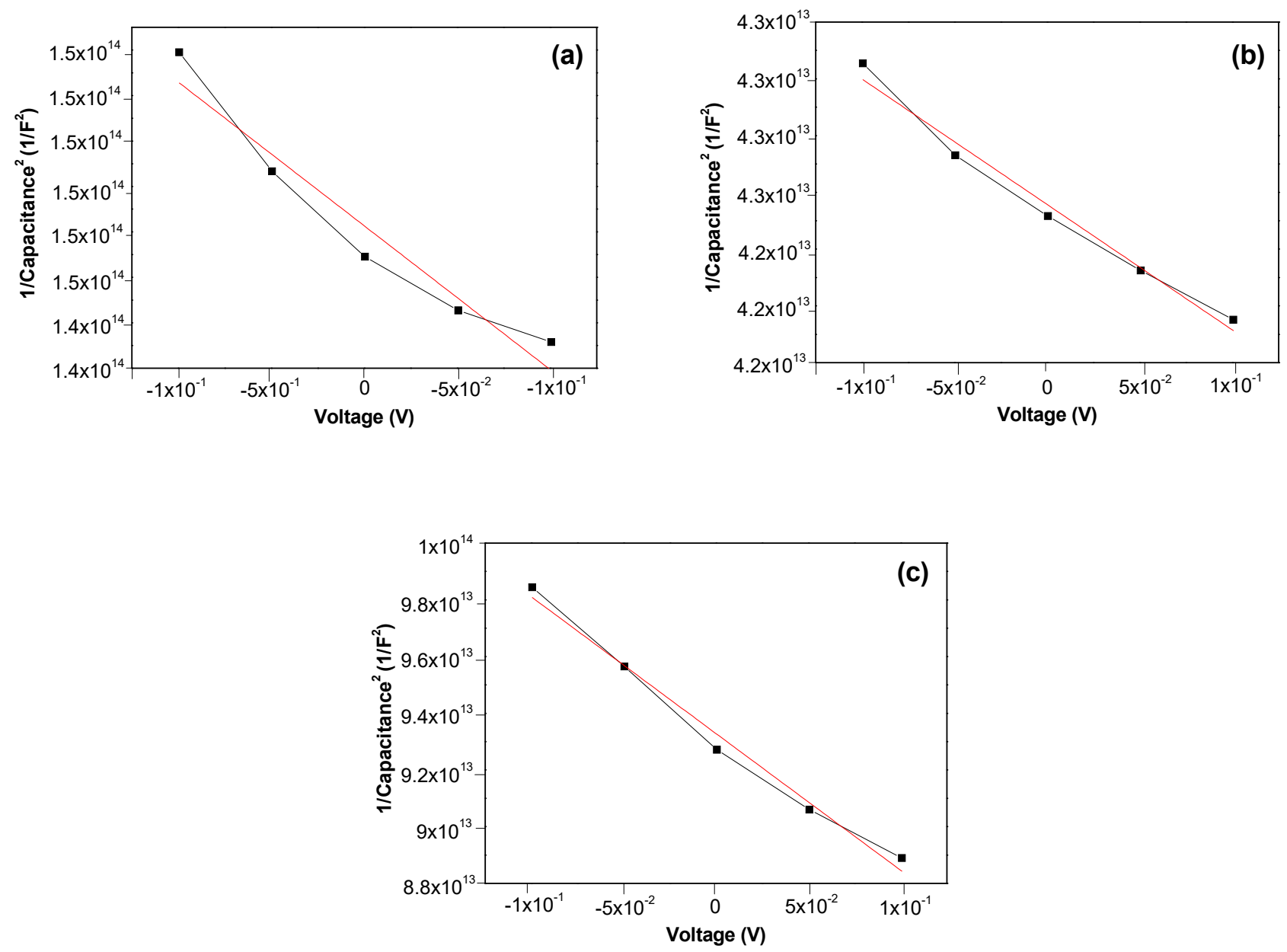

Figure 6. Mott-Schottky plots of the capacitance of (a) ZnO, (b) ZnO:Na, and (c) ZnO:K onto soda-lime glass.

The conduction mechanism could be determined by the polarity carrier concentration. Figure 6 shows that the value of the slope was negative in all the dopants; as a result, the polarity carrier concentration was negative, so it concludes that films are n-type. This linearity deviation in the Mott-Schottky plots may be associated with the polycrystalline nature of the samples and high interface defects. $\mathrm{ZnO}$ is considered n-type semiconductor due to a large number of point defects, Zn vacancy or interstitial sites, as well as oxygen vacancy [47]. $\mathrm{ZnO}$ could have either $\mathrm{Zn}$ interstitial or oxygen vacancy or both, which lead to the excess unpaired electron that enhances n-type conductivity [48]. The oxygen vacancy has frequently been associated as the source of unintentional n-type conductivity, but recent researches indicate that this assignment cannot be correct [49]. However, this is statement is not useful for any elements. Hence, p-type conduction in $\mathrm{ZnO}$ requires the incorporation of shallow acceptor levels which may be possible by substituting monovalent atoms (as elements from the group I) at $\mathrm{Zn}$ sites that create one hole per alkali atom in the neighboring oxygen atom. However, the literature has reported that group-I elements $(\mathrm{Na}$, $\mathrm{K})$ tend to occupy the interstitial site, thereby acting as a donor, not as an acceptor [48]. 
Table 1 shows that all the thin films regardless the dopant exhibit n-type conduction, whereas the Na doping n-type conduction may be related to the increase in the donor-like $\mathrm{V}_{0}$ density and the compensation of $\mathrm{Na}_{\mathrm{i}}$ for the $\mathrm{Na}_{\mathrm{Zn}}$ acceptor. The conduction mechanism for the $\mathrm{K}$ doping shows that $\mathrm{n}$-type conduction behavior had arisen due to the preferential occupation of $\mathrm{K}$ into the interstitial sites and acted as donors to supply electrons [50]. The samples show electron conduction behavior (n-type) with a carrier concentration in the region of $\sim 10^{18} \mathrm{~cm}^{-3}$. It is important to note that a solid solution of $\mathrm{Na}$, and $\mathrm{K}$-doped $\mathrm{ZnO}$ increase the carrier concentration of the undoped $\mathrm{ZnO}$ thin film.

\section{Conclusions}

We developed very low resistant and highly transparent alkali-doped $\mathrm{ZnO}$ thin films for transparent conductive oxide applications by an easy low-cost spray pyrolysis technique. The structural, morphological, optical, and electrical properties of the coating with composition $\mathrm{Zn}_{1-\mathrm{x}} \mathrm{M}_{\mathrm{x}} \mathrm{O}(\mathrm{x}=0.03)$ were characterized. All samples crystallize in a single hexagonal phase of wurtzite structure with preferred c-axis orientation along a (002) crystal plane. Highly transparent layers were obtained with an average optical transmittance of $80 \%$. The energy band gap of doped $\mathrm{ZnO}$ films increased from 3.27 to $3.29 \mathrm{eV}$ by a rising of the atomic number of dopants. The samples show n-type electron conduction behavior with a carrier concentration in the region of $\sim 10^{18} \mathrm{~cm}^{-3}$. The alkali-doped $\mathrm{ZnO}$ films obtained by the easy and low-cost method has great potential for photovoltaics (PV) as interconnecting layer in tandem technology based on the monolithic integration of interdigitated back-contacted c-Si solar cells devices as bottom cells, with wide band-gap semi-transparent kesterite top cells in a four contacts configuration, this being compatible with future industrialization of the technology.

Author Contributions: Conceptualization, J.B.C. and D.F.; methodology, S.P.; software, T.S.-L.; validation, T.S.-L.; investigation, S.P. and J.G.C.; writing—original draft preparation, S.P.; writing-review and editing, D.F. and T.S.-L.; supervision, J.B.C. and D.F.; project administration, J.B.C.; funding acquisition, J.B.C. All authors have read and agreed to the published version of the manuscript.

Funding: Spanish Ministry of Economy and Competitiveness under the program Programa Estatal de I+D+I orientada a los retos de la sociedad in the framing of the IGNITE project (ENE2017-87671C3-3-R) and Proyecto PID2020-116719RB-C43 financiado por MCIN/AEI/10.13039/501100011033.

Institutional Review Board Statement: Not applicable.

Informed Consent Statement: Not applicable.

Data Availability Statement: Not applicable.

Acknowledgments: The authors would like to acknowledge the financial support of the Spanish Ministry of Economy and Competitiveness under the program Programa Estatal de I+D+i orientada a los retos de la sociedad in the framing of the IGNITE project (ENE2017-87671-C3-3-R) and the program Proyectos de $\mathrm{I}+\mathrm{D}+\mathrm{i} »$ de los Programas Estatales de Generación de Conocimiento y Fortalecimiento Científico y Tecnológico del Sistema de I+D+i y de I+D+i Orientada a los Retos de la Sociedad, en el marco del Plan Estatal de Investigación Científica y Técnica y de Innovación 2017-2020 (Ref. PID2020-116719RB-C43). We also appreciate the characterization assistance of Central Service of Scientific Instrumentation (SCIC) at the University Jaume I. We also thank the group of A. Perez (IREC) and the group of F. Fabregat (INAM-UJI) for the analysis and characterization assistance.

Conflicts of Interest: The authors declare no conflict of interest.

\section{References}

1. Ferhati, H.; Djeffal, F.; Kacha, K.; Bendjerad, A.; Benhaya, A. Influence of TCO intermediate thin-layers on the electrical and thermal properties of metal/TCO/p-Si Schottky structure fabricated via RF magnetron sputtering. Phys. E Low-Dimens. Syst. Nanostruct. 2019, 106, 25-30. [CrossRef]

2. Cruz, A.; Wang, E.C.; Morales-Vilches, A.B.; Meza, D.; Neubert, S.; Szyszka, B.; Schlatmann, R.; Stannowski, B. Effect of front TCO on the performance of rear-junction silicon heterojunction solar cells: Insights from simulations and experiments. Sol. Energy Mater. Sol. Cells 2019, 195, 339-345. [CrossRef] 
3. Çolak, H.; Karaköse, E. Tm-DOPED ZnO NANORODS as a TCO for PV Applications. J. Rare Earths 2018, 36, 1067-1073. [CrossRef]

4. Todorov, T.K.; Bishop, D.M.; Lee, Y.S. Materials perspectives for next-generation low-cost tandem solar cells. Sol. Energy Mater. Sol. Cells 2018, 180, 350-357. [CrossRef]

5. Aouaj, M.A.; Diaz, R.; Belayachi, A.; Rueda, F.; Abd-Lefdil, M. Comparative study of ITO and FTO thin films grown by spray pyrolysis. Mater. Res. Bull. 2009, 44, 1458-1461. [CrossRef]

6. Thampy, A.S.; Dhamodharan, S.K. Performance analysis and comparison of ITO-and FTO-based optically transparent terahertz U-shaped patch antennas. Phys. E Low-Dimens. Syst. Nanostruct. 2015, 66, 52-58. [CrossRef]

7. Han, C.H.; Han, S.D.; Gwak, J.; Khatkar, S.P. Synthesis of indium tin oxide (ITO) and fluorine-doped tin oxide (FTO) nano-powder by sol-gel combustion hybrid method. Mater. Lett. 2007, 61, 1701-1703. [CrossRef]

8. Bisht, H.; Eun, H.T.; Mehrtens, A.; Aegerter, M.A. Comparison of spray pyrolyzed FTO, ATO and ITO coatings for flat and bent glass substrates. Thin Solid Films 1999, 351, 109-114. [CrossRef]

9. Kawashima, T.; Matsui, H.; Tanabe, N. New transparent conductive films: FTO coated ITO. Thin Solid Films 2003, 445, 241-244. [CrossRef]

10. Cho, S.W.; Kim, Y.B.; Kim, D.E.; Kim, K.S.; Yoon, Y.D.; Kang, W.J.; Lee, W.; Cho, H.K.; Kim, Y.H. The pH-dependent corrosion behavior of ternary oxide semiconductors and common metals and its application for solution-processed oxide thin film transistors circuit integration. J. Alloy. Compd. 2017, 714, 572-582. [CrossRef]

11. Aydogan, S.; Yilmaz, M. Crystallographic disorders depending on monovalent cations addition and their effects on ZnO's characteristics. Ceram. Int. 2020, 46, 8420-8430. [CrossRef]

12. Baruah, S.; Dutta, J. Hydrothermal growth of ZnO nanostructures. Sci. Technol. Adv. Mater. 2009, 10, 013001. [CrossRef]

13. Mahmood, A.; Naeem, A. Sol-Gel-Derived Doped ZnO Thin Films: Processing, Properties, and Applications. In Recent Applications in Sol-Gel Synthesis; Intech Open: London, UK, 2017; pp. 169-193. [CrossRef]

14. Kegel, J.; Povey, I.M.; Pemble, M.E. Zinc oxide for solar water splitting: A brief review of the material's challenges and associated opportunities. Nano Energy 2018, 54, 409-428. [CrossRef]

15. Marouf, S.; Beniaiche, A.; Kardarian, K.; Mendes, M.J.; Sanchez-Sobrado, O.; Águas, H.; Fortunato, E.; Martins, R. Lowtemperature spray-coating of high-performing ZnO:Al films for transparent electronics. J. Anal. Appl. Pyrolysis 2017, 127, 299-308. [CrossRef]

16. Ynineb, F.; Attaf, N.; Aida, M.S.; Bougdira, J.; Bouznit, Y.; Rinnert, H. Morphological and optoelectrical study of ZnO:In/p-Si heterojunction prepared by ultrasonic spray pyrolysis. Thin Solid Films 2017, 628, 36-42. [CrossRef]

17. Mondal, P.; Das, D. Further improvements in conducting and transparent properties of ZnO:Ga films with perpetual c-axis orientation: Materials optimization and application in silicon solar cells. Appl. Surf. Sci. 2017, 411, 315-320. [CrossRef]

18. Seawsakul, K.; Horprathum, M.; Eiamchai, P.; Pattantsetakul, V.; Limwichean, S.; Muthitamongkol, P.; Thanachayanont, C.; Songsiriritthigul, P. Glancing-angle pulsed dc magnetron sputtered AZO thin films for TCO applications. Mater. Today Proc. 2018, 5, 14166-14171. [CrossRef]

19. Wu, J.; Wang, Z.; Chen, F.; Shen, Q.; Zhang, L. Chemical evolution of target surfaces during RF magnetron sputtering and its effect on the performance of TCO films. Appl. Surf. Sci. 2019, 493, 665-672. [CrossRef]

20. Bedia, A.; Bedia, F.Z.; Aillerie, M.; Maloufi, N. Structural, electrical and optical properties of Al-Sn codoped ZnO transparent conducting layer deposited by spray pyrolysis technique. Superlattices Microstruct. 2017, 111, 714-721. [CrossRef]

21. Ye, Z.; Wang, T.; Wu, S.; Ji, X.; Zhang, Q. Na-doped ZnO nanorods fabricated by chemical vapor deposition and their optoelectrical properties. J. Alloy. Compd. 2017, 690, 189-194. [CrossRef]

22. Li, Y.; Zhang, Y.; He, H.; Ye, Z.; Jiang, J.; Cao, L. Growth of Na doped p-type non-polar a-plane ZnO films by pulsed laser deposition. Mater. Lett. 2012, 76, 81-83. [CrossRef]

23. Tay, C.B.; Chua, S.J.; Loh, K.P. Stable p-type doping of ZnO film in aqueous solution at low temperatures. J. Phys. Chem. C 2010, 114, 9981-9987. [CrossRef]

24. Zhang, J.; Tse, K.; Wong, M.; Zhang, Y.; Zhu, J. A brief review of co-doping. Front. Phys. 2016, 11, 117405. [CrossRef]

25. Bu, I.Y.Y. Direct formation of p-type ZnO by using potassium hydroxide. Optik 2018, 159, 87-93. [CrossRef]

26. Kaneva, N.; Stambolova, I.; Blaskov, V.; Dimitriev, Y.; Bojinova, A.; Dushkin, C. A comparative study on the photocatalytic efficiency of $\mathrm{ZnO}$ thin films prepared by spray pyrolysis and sol-gel method. Surf. Coat. Technol. 2012, 207, 5-10. [CrossRef]

27. Zhao, J.L.; Li, X.M.; Zhang, S.; Yang, C.; Gao, X.D.; Yu, W.D. Highly (002)-oriented ZnO film grown by ultrasonic spray pyrolysis on ZnO-seeded Si (100) substrate. J. Mater. Res. 2006, 21, 2185-2190. [CrossRef]

28. Murti, D.K.; Bluhm, T.L. Preferred orientation of ZnO films controlled by r.f. sputtering. Thin Solid Films 1982, 87, 57-61. [CrossRef]

29. Janotti, A.; Van De Walle, C.G. Fundamentals of zinc oxide as a semiconductor. Rep. Prog. Phys. 2009, 72, 126501. [CrossRef]

30. Erhart, P.; Albe, K. First-principles study of migration mechanisms and diffusion of oxygen in zinc oxide. Phys. Rev. B 2006, 73, 115207. [CrossRef]

31. Ilican, S. Effect of Na doping on the microstructures and optical properties of ZnO nanorods. J. Alloy. Compd. 2013, 553, 225-232. [CrossRef]

32. Guan, S.; Watabe, T.; Hao, L.; Yoshida, H.; Cheng, Y.; Zhou, K.; Lu, Y. Enhanced photocatalytic activity of potassium-doped titania photocatalyst films with nanosheet structure. Mater. Lett. 2019, 242, 174-178. [CrossRef] 
33. Purbayanto, M.A.K.; Rusydi, A.; Darma, Y. The effect of crystallinity on the surface modification and optical properties of ZnO thin films. Phys. Chem. Chem. Phys. 2020, 22, 2010-2018. [CrossRef]

34. Chen, M.; Wang, X.; Yu, Y.H.; Pei, Z.L.; Bai, X.D.; Sun, C.; Huang, R.F.; Wen, L.S. X-ray photoelectron spectroscopy and auger electron spectroscopy studies of Al-doped ZnO films. Appl. Surf. Sci. 2000, 158, 134-140. [CrossRef]

35. Hsieh, P.T.; Chen, Y.C.; Kao, K.S.; Wang, C.M. Luminescence mechanism of ZnO thin film investigated by XPS measurement. Appl. Phys. A 2008, 90, 317-321. [CrossRef]

36. Szörényi, T.; Laude, L.D.; Bertóti, I.; Kántor, Z.; Geretovszky, Z. Excimer laser processing of indium-tin-oxide films: An optical investigation. J. Appl. Phys. 1995, 78, 6211-6219. [CrossRef]

37. Ratana, T.; Amornpitoksuk, P.; Ratana, T.; Suwanboon, S. The wide band gap of highly oriented nanocrystalline Al doped ZnO thin films from sol-gel dip coating. J. Alloy. Compd. 2009, 470, 408-412. [CrossRef]

38. Qiu, J.; Guo, B.; Zhang, H.; Yu, C.; Li, F. Insights into Working Mechanism of Alkali Metal Fluorides as Dopants of ZnO Films in Inverted Polymer Solar Cells. J. Phys. Chem. C 2018, 122, 24542-24549. [CrossRef]

39. Smits, F.M. Measurement of Sheet Resistivities with the Four-Point Probe. Bell Syst. Tech. J. 1958, 37, 711-718. [CrossRef]

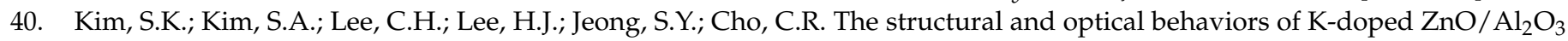
(0001) films. Appl. Phys. Lett. 2004, 85, 419-421. [CrossRef]

41. Gelderman, K.; Lee, L.; Donne, S.W. Flat-band potential of a semiconductor: Using the Mott-Schottky equation. J. Chem. Educ. 2007, 84, 685-688. [CrossRef]

42. Pedemonte, M.M. Estudios Fisicoquímicos Sobre Materiales Basados enel $\mathrm{TiO}_{2}$ Relacionados con la Foto-Descomposición de Agua y el Desarrollo de Celdas Solares Foto-Electroquímicas. Ph.D. Thesis, Universidad Nacional de La Plata, Provincia de Buenos Aires, Argentina, 2011.

43. Singh, B.K.; Tripathi, S. Performance analysis of Schottky diodes based on Bi doped p-ZnO thin films. Superlattices Microstruct. 2018, 120, 288-297. [CrossRef]

44. Le Bourhis, E. Glass: Mechanics and Technology, 2nd ed.; Wiley: Hoboken, NJ, USA, 2014. [CrossRef]

45. Reeber, R.R. Lattice parameters of zno from 4.2 to 296 k. J. Appl. Phys. 1970, 41, 5063-5066. [CrossRef]

46. Van De Walle, C.G. Hydrogen as a cause of doping in zinc oxide. Phys. Rev. Lett. 2000, 85, 1012-1015. [CrossRef] [PubMed]

47. Stamataki, M.; Tsamakis, D.; Xanthakis, J.P.; Ali, H.A.; Esmaili-Sardari, S.; Iliadis, A.A. Electrical characterization of Cr Schottky contacts on undoped and Ni-doped p-ZnO films grown by pulsed laser deposition on Si (1 00 ) substrates. Microelectron. Eng. 2013, 104, 95-99. [CrossRef]

48. Akcan, D.; Gungor, A.; Arda, L. Structural and optical properties of Na-doped ZnO films. J. Mol. Struct. 2018, 1161, $299-305$. [CrossRef]

49. Zhang, G.; Pan, C.; Zhou, Q. Effects of doping Na on the structure and physical properties of $\mathrm{La}_{2 / 3} \mathrm{Ca}_{1 / 3} \mathrm{MnO}_{3}$. Solid State Commun. 2007, 141, 471-473. [CrossRef]

50. Xu, L.; Li, X.; Yuan, J. Effect of K-doping on structural and optical properties of ZnO thin films. Superlattices Microstruct. 2008, 44, 276-281. [CrossRef] 